\title{
Prediction of In Situ Ruminal Degradability of Forages in Buffaloes Using the In Vitro Gas Production Technique
}

\author{
G.F. Guadayo ${ }^{\text {a }}$, A.A. Rayos ${ }^{\mathrm{b}}$, F.E. Mercac ${ }^{\mathrm{c}}$, A.G. Tandang ${ }^{\mathrm{d}}$, M.M. Loresco ${ }^{\mathrm{a}}$, \& A.A. Angeles ${ }^{\mathrm{a}, *}$ \\ ${ }^{a}$ Dairy Training and Research Institute, College of Agriculture and Food Science, \\ University of the Philippines Los Baños, Laguna, Philippines \\ ' Institute of Animal Science, College of Agriculture and Food Science, University of the Philippines Los Baños, \\ Laguna, Philippines \\ 'Institute of Chemistry, College of Arts and Sciences, University of the Philippines Los Baños, Laguna, Philippines \\ dPhilippine Carabao Center at University of the Philippines Los Baños, Laguna, Philippines \\ ${ }^{*}$ Corresponding author: aaangeles8@up.edu.ph \\ (Received 31-10-2018; Revised 14-03-2019; Accepted 13-03-2019)
}

\begin{abstract}
Two experiments, namely the situ nylon bag technique and the in vitro gas production technique, were carried out to determine the correlations between the in situ ruminal degradability and the in vitro gas production of different forages, and to predict the ruminal degradability of the forages using the gas production parameters. Forage samples from Napier grass (Pennisetum purpureum), Guinea grass (Panicum maximum), Para grass (Brachiaria mutica), Leucaena (Leucaena leucocephala), Rain tree (Samanea saman), and Gliricidia (Gliricidia sepium) were incubated in the rumen of three rumen-cannulated buffaloes using the in situ nylon bag technique for 3, 6, 12, 24, 48, and $72 \mathrm{~h}$. The six forage samples were also subjected to the in vitro gas production analysis following the modified methods developed by Menke \& Steingass (1988), along with 30 other commonly used forages in the Philippines. Both experiments followed a randomized complete block design. Their dry matter (DM), organic matter $(\mathrm{OM})$, neutral detergent fiber $(\mathrm{NDF})$, and crude protein $(\mathrm{CP})$ degradation kinetics and effective degradability (ED) as well as the gas production parameters were then estimated. Results revealed that the ED of each nutrient was found to be moderately to strongly correlated with some of the gas production times and estimated gas parameters. The predictor models generated using the gas production parameters for the ED of DM, OM, and NDF were sufficiently strong $\left(R^{2}=0.740, p\right.$ value= $0.0002 ; R^{2}=0.659$, $p$ value $=0.0009$; and $R^{2}=0.813$, $p$ value $<0.0001$, respectively) while that of $C P$ was only moderate $\left(R^{2}=0.500, p\right.$ value $\left.=0.0055\right)$. It was concluded that the relationship between the two techniques is sufficiently strong and therefore the gas production parameters can be used to predict the in situ ruminal nutrient degradability of forages.
\end{abstract}

Keywords: grasses; legumes; nutrient degradability; predictor models

\section{INTRODUCTION}

The digestibility or degradability coefficient of a feed ingredient is one important factor to consider in evaluating its nutritive value. The potential value of a feed ingredient can be determined through various chemical analyses. Its actual value, however, can only be determined using digestibility or degradability coefficients (McDonald et al., 2010). In ruminants, the rumen degradability, i.e. the proportion of a feedstuff that is degraded in the rumen, can be estimated through various in situ and in vitro studies. The in situ nylon bag technique is one way of estimating the degradability of feedstuffs (Mehrez \& Ørskov, 1977). The sample to be analyzed is enclosed in a nylon bag and incubated in the rumen of a cannulated animal and the disappearance of the sample at any one point can be predicted mathematically. Although regarded as the reference technique in evaluating ruminant feed ingredients (Cone et al., 2009), the in situ nylon bag technique is laborious and can be prone to some sources of inaccuracies. One of which is the colonization of the residues by the rumen microbes which may cause the protein degradability to be underestimated (Edmunds et al., 2012). Another method is the gas production analysis, an in vitro technique which makes use of the principles of gas production from fermentation of feeds by microorganisms in the rumen (Menke et al., 1988). In vitro degradability techniques like the gas production technique allow the completion of multiple samples' degradability determination in a shorter period of time (Mohamed \& Chaudhry, 2008; Karlsonn et al., 2009).

The in vitro gas production technique has been correlated with the in situ nylon bag technique, the most extensively used ruminant feed evaluation method, in past studies because it is relatively much faster and easier to 
perform and can reasonably predict the in situ ruminal degradability of forage samples. Ozkan \& Sahin (2006) and Kamalak et al. (2005) compared the in vitro gas production technique with the in situ nylon bag technique. Their studies revealed that there is a sufficiently strong correlation between the parameters obtained from the two methods and that the gas production method can be used as an alternative to the more laborious nylon bag technique.

Degradability coefficients are crucial in avoiding overestimates of the nutritional value of a feed ingredient by accounting for the inevitable losses that occur during digestion and metabolism of the animal (McDonald et al., 2010). Moreover, degradability values of some forages are outdated, incomplete or unavailable in feed reference manuals. Developing an effective and efficient method in predicting the in situ ruminal degradability of feed samples was one of the core objectives of the present study.

The general objective of this study was to predict the ruminal degradability of dry matter (DM), organic matter (OM), neutral detergent fiber (NDF), and crude protein $(\mathrm{CP})$ of commonly used forages in the Philippines using the in vitro gas production technique.

\section{MATERIALS AND METHODS}

\section{Experimental Animals and Diet}

The present study is comprised of two components: the in situ incubation (Experiment 1 ) and the in vitro gas production (Experiment 2) of the forages. Both experiments made use of three rumen-cannulated buffaloes: a 13-year-old male Bulgarian Murrah; a 9-year-old male 50:50 cross of Philippine Native and Murrah; and a 3-year-old male 50:50 cross of Philippine Native and Murrah. The cannulation was carried out by licensed veterinarians and the surgery, care, and feeding of the animals were in accordance to the regulations set by the Institutional Animal Care and Use Committee (IACUC). Preliminary weight range of the animals before fitting of cannulas was $450-720 \mathrm{~kg}$.

During the degradability trials, the animals were fed ration containing 70\% roughage (Napier grass, 60-90 days) and 30\% concentrate feed (NLT 16\% CP) equivalent to $3 \%$ of their body weights (BW) in DM basis. The specifications of the concentrate is shown in Table 1. The experimental animals were fed the diet at 0830 and 1400 $\mathrm{h}$ and were given free access to clean water and mineral licks.

\section{Experiment 1. Determination of In Situ Degradability of DM, OM, NDF, and CP}

The samples that underwent ruminal incubation were Napier grass (Pennisetum purpureum), Guinea grass (Panicum maximum), Para grass (Brachiaria mutica), Leucaena leaves (Leucaena leucocephala), Rain tree leaves (Samanea saman), and Gliricidia leaves (Gliricidia sepium). These samples were chosen because they are some of the most commonly used grasses and legume forages for ruminants in the Philippines. Para grass was harvested at a 56-day regrowth while Napier and Guinea grasses were cut at a 45-day regrowth. The legume samples were harvested from mature trees, vines or shrubs. Prior to in situ rumen incubation, collected samples were prepared by oven-drying at $70^{\circ} \mathrm{C}$ for 3 days and grinding to pass through $2 \mathrm{~mm}$ particle size (Laboratory Mill 3310, Perten Instruments $A B$, Hägersten, Sweden). Three grams of the ground samples were placed in a $9 \times 15 \mathrm{~cm}$ digestion bag made from a blend of polyester and silk, with 40-60 microns perforation sewn with a double line technique using a polyester thread.

Each sample was incubated in triplicates in the rumen of the cannulated buffaloes following a randomized complete block design for 3, 6, 12, 24, 48, and $72 \mathrm{~h}$. The gradually in-all out method was used, i.e. the bags were placed in the rumen at designated time points and retrieved all at once. After removal from the rumen, the bags were washed with running water until washings become clear and then dried to constant weight at $70^{\circ} \mathrm{C}$ for 3 days. Inconsistencies in the loss in weight during the washing of the samples with running water after the incubation were corrected by soaking control samples in water then washing and drying them normally (Ørskov et al., 1980). Control bags were also incubated in the rumen at similar time intervals as the samples to correct for the changes in weight of the bags due to soaking in rumen liquor.

Each fraction of the sample withdrawn at an incubation time was subjected to moisture (oven-drying), crude protein (Kjeldahl digestion), ash (ignition), and neutral detergent fiber (Van Soest method) determinations following the official methods of analysis developed by AOAC (2016). Representatives of each sample in duplicate before incubation were also subjected to the aforementioned chemical analyses.

Ruminal degradabilities of DM, OM, NDF, and $\mathrm{CP}$ of the grasses and legumes were then estimated by fitting the data to the exponential equation (Eq. 1) proposed by Ørskov \& McDonald (1979):

$$
y=a+b\left(1-e^{-c t}\right)
$$

where $y$ is $\mathrm{DM}, \mathrm{OM}, \mathrm{NDF}$, or $\mathrm{CP}$ disappearance in rumen (\%) at time $t, a$ is the rapidly soluble fraction (\%), $b$ is the potentially degradable fraction $(\%), c$ is the con-

Table 1. Specifications of the grower concentrate offered

\begin{tabular}{lc}
\hline Chemical composition/ ingredient & Specification (\%) \\
\hline Total digestible nutrient & $\min 80$ \\
Crude protein & $\min 16$ \\
Crude fat & $\min 4$ \\
Total calcium & $0.9-1.2$ \\
Total phosphorus & $0.5-0.6$ \\
Sodium & $\min 0.4$ \\
Salt & $0.7-1$ \\
Restrictions: & \\
$\quad$ Copra meal & $\max 30$ \\
$\quad$ Rice bran D1 & $\max 25$ \\
$\quad$ Palm kernel meal & $\max 30$ \\
\hline
\end{tabular}


stant rate of degradation of $\mathrm{b}(\% / \mathrm{h})$, and $t$ is incubation time.

The model parameters were estimated using the non-linear procedure of GraphPad Prism 7 (GraphPad Software, Inc., San Diego, CA). Separate curves were fitted to the data points of each replicate. The effective $\mathrm{DM}, \mathrm{OM}, \mathrm{NDF}$, and $\mathrm{CP}$ degradabilities were then calculated (Eq. 2) by assuming a rumen outflow rate of $2 \% / \mathrm{h}$ (recommended rate for animals at maintenance level; NRC, 2001):

$$
E D=a+(b c /(c+k))
$$

where (a), (b), and (c) are the same as in Eq. 1 and (k) is the rumen outflow rate.

\section{Experiment 2. In Vitro Gas Production Experiment}

The six forage species tested in Experiment 1 along with 30 other forages (Table 8) were used in Experiment 2. Sample preparation was similar as in Experiment 1. Rumen fluid was collected from each buffalo $3 \mathrm{~h}$ after the morning feeding. Rumen fluid squeezed from rumen contents was filtered through 3 layers of cheese cloth into a beaker and immediately transferred and sealed without air into zip lock polyethylene bags. The bags were kept inside a polystyrene box with warm water having an internal temperature of $38-41^{\circ} \mathrm{C}$ until the in vitro gas production incubation.

In situ DM, OM, NDF, and CP degradabilities for each sample were predicted using the rumen fluid gas production technique based on the modified methods of Menke \& Steingass (1988). Collected rumen fluid was immediately transferred to a $50 \mathrm{~mL}$ syringe (Terumo) containing $200 \mathrm{mg}$ dry matter of the sample, $5 \mathrm{~mL} 0.05$ $\mathrm{M} \mathrm{K}-\mathrm{PO}_{4}$ buffer $\mathrm{pH} 6.5$ and $1 \mathrm{~mL} 0.154 \mathrm{M} \mathrm{MgSO}_{4}$ to attain a final volume of $15 \mathrm{~mL}$. The mixture was sealed at the Luer lock of the syringe with hot-melt adhesive after making sure that the liquid occupied all the space inside the syringe. Duplicates of each sample together with the blanks (mixture without samples) were incubated immediately in an oven at $39^{\circ} \mathrm{C}$. Gas produced was measured using the graduation of the syringe with readings taken at $0,3,6,12,24,48$, and $72 \mathrm{~h}$ of incubation. Data were also fitted to the model of Ørskov \& McDonald (1979) (Eq. 1) except that the parameters a, b, and c were associated with gas production instead of DM degradation. The gas production kinetics were also estimated using the non-linear procedure of GraphPad Prism 7.

\section{Statistical Analysis}

One-way analysis of variance (ANOVA) was performed using the PROC GLM of SAS 9.1.3 (SAS Inst.
Inc., Cary, NC) to determine significant differences in the means of the estimated degradation and gas production parameters among the samples. The animals and the source of rumen fluid were treated as the blocks for the in situ experiment and the in vitro experiment, respectively. Pairwise mean comparisons were done using the PDIFF command with the Tukey-Kramer adjustment of SAS. The correlations between the model parameters from the two incubation techniques were determined using the CORR procedure of SAS. Significance level was set to $\alpha=0.05$. The first step in the development of the prediction models was to determine the existence of multi-collinearity among the independent variables using the VIF option in the MODEL statement of the REG procedure of SAS. Extreme observations which have a possibility to have a high influence on regression estimation were also checked by using the INFLUENCE option in the MODEL statement. Then, the conceptual predictive criterion $[C(p)]$ was used to determine the candidate models that maximize explained variability with as few variables as possible. The next step was the use of the multiple regression analysis in SAS, in which the model statements included the variables found in the identified candidate models. The best regression model was determined by considering the $\mathrm{R}^{2}$, Akaike information criterion (AIC), root mean square error (RMSE), and the $\mathrm{p}$ value of each candidate model.

\section{RESULTS}

\section{Nutrient Composition of the Samples}

Table 2 shows the nutrient compositions in a dry matter basis of the samples that were subjected to rumen incubation. It can be observed that the CP of the legumes is considerably higher than that of the grasses. On the other hand, NDF is generally higher in the grasses than in the legumes.

\section{In Situ Degradability of DM, OM, NDF, and CP}

The nutrient degradation curves and the estimated nutrient degradation kinetics of the six samples are presented in Figures 1a-1d and Table 3, respectively.

Dry matter degradation. With the exception of Rain tree leaves, the samples follow a standard non-linear DM degradation curve wherein majority of the degradable fraction disappear from the bag within the first 24 hours. Rain tree leaves follow a more horizontal DM degradation curve which suggests a limited degradability (Figure 1a).

Table 2. Initial chemical compositions in a dry matter basis of the grasses and legumes subjected to the in situ incubation experiment

\begin{tabular}{lcccccccc}
\hline \multirow{2}{*}{ Chemical composition (\%) } & \multicolumn{3}{c}{ Legumes } & & \multicolumn{3}{c}{ Grasses } \\
\cline { 2 - 4 } \cline { 6 - 8 } & Rain tree leaves & Leucaena leaves & Gliricidia leaves & & Napier grass & Para grass & Guinea grass \\
\hline Dry matter & 44.05 & 30.51 & 25.21 & & 16.97 & 21.60 & 34.56 \\
Organic matter & 93.82 & 92.57 & 90.48 & & 80.18 & 86.99 & 89.87 \\
Crude protein & 20.21 & 18.96 & 19.27 & & 8.92 & 6.92 & 7.23 \\
Neutral detergent fiber & 61.22 & 57.32 & 51.48 & & 69.31 & 81.48 & 81.25 \\
\hline
\end{tabular}




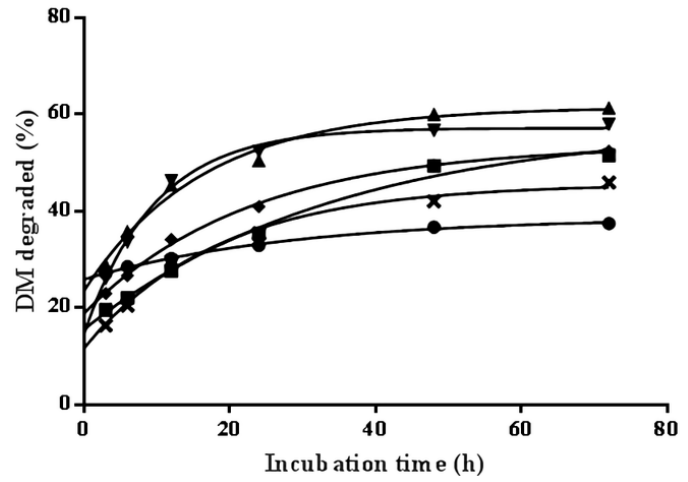

Figure 1a. Dry matter (DM) degradation profiles of the samples that underwent ruminal incubation; - $\bullet$ - rain tree leaves; - $\boldsymbol{-}$ - Leucaena leaves; - $\boldsymbol{\Delta}$ - Gliricidia leaves; - $\boldsymbol{\nabla}$ Napier grass; - - - Para grass; -x- Guinea grass.

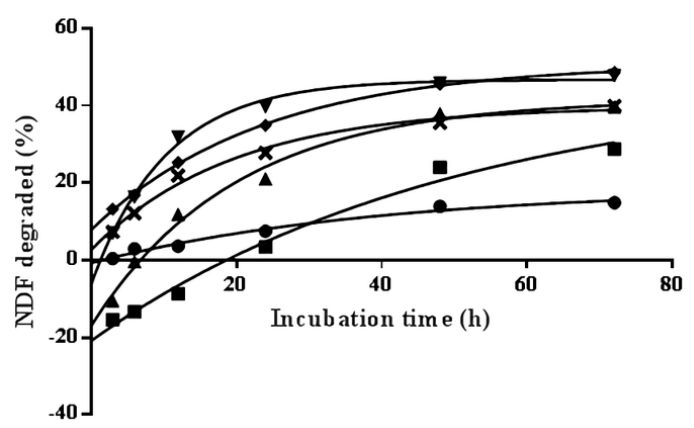

Figure 1c. Neutral detergent fiber (NDF) degradation profiles of the samples that underwent ruminal incubation; - $\bullet$ rain tree leaves; - - Leucaena leaves; - $\boldsymbol{\Delta}$ - Gliricidia leaves; - $\mathbf{\nabla}$ - Napier grass; - - - Para grass; -×- Guinea grass.

Rapidly soluble DM fractions (a) were greatest $(\mathrm{p}<0.001)$ in Rain tree and Gliricidia leaves. The potentially degradable fraction (b) of Rain tree leaves were lower $(\mathrm{p}<0.001)$ than the rest of the samples. As a result, the calculated effective degradability (ED) of Rain tree leaves was the lowest $(p<0.001)$ among the six samples. Gliricidia leaves had the greatest $(\mathrm{p}<0.001)$ calculated ED together with Napier grass.

Organic matter degradation. The rapidly soluble OM fractions and potentially degradable OM fractions of the samples follow similar trends with the parameter counterparts from their DM degradation (Figure 1b). However, the rapidly soluble fraction of Napier grass was negative. This means that the OM degradation for Napier grass has an initiation period before the actual degradation begins. As with their DM ED, Gliricidia leaves and Napier grass had the greatest $(\mathrm{p}<0.001)$ estimated OM ED.

Neutral detergent fiber degradation. It is worth noting that the NDF degradation curves of some of the samples used in the experiment had negative degradability values at earlier incubation periods (Figure 1c).

The calculated potentially degradable fractions of Leucaena and Gliricidia leaves were the greatest $(\mathrm{p}<0.001)$ among the six samples. However, this may be attributed to the negative NDF degradation measure-

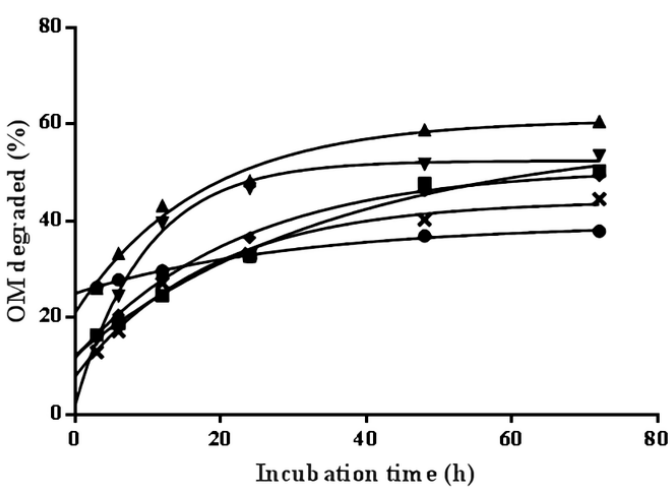

Figure 1b. Organic matter (OM) degradation profiles of the samples that underwent ruminal incubation; - $\bullet$ - rain tree leaves; - - Leucaena leaves; - $\boldsymbol{\Delta}$ - Gliricidia leaves; - $\boldsymbol{\nabla}$ Napier grass; - - - Para grass; -x- Guinea grass.

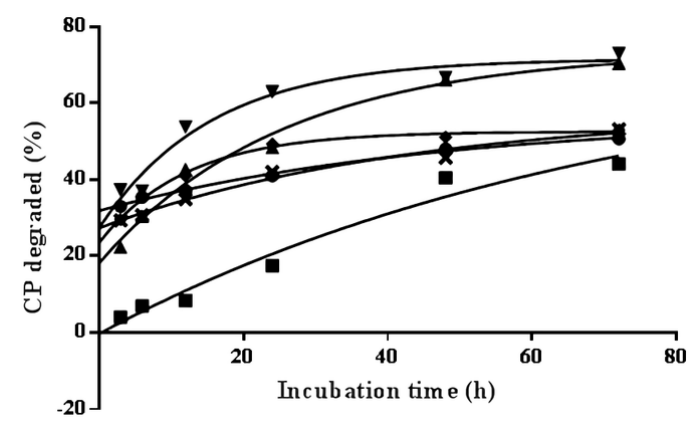

Figure 1d.Crude protein $(\mathrm{CP})$ degradation profiles of the samples that underwent ruminal incubation; - $\bullet$ - rain tree leaves; - $\boldsymbol{-}$ - Leucaena leaves; - $\boldsymbol{\Lambda}$ - Gliricidia leaves; - $\boldsymbol{\nabla}$ Napier grass; - - - Para grass; -x- Guinea grass.

ments of the two samples. Rain tree leaves, on the other hand, had the lowest $(\mathrm{p}<0.001)$ potentially degradable fraction. The calculated ED of the grasses were greater $(p<0.001)$ than those of the legumes.

Crude protein degradation. Leucaena leaves had the lowest $(P<0.001)$ estimate for the rapidly soluble CP fraction, which was negative (Figure 1d). Consequently, the calculated ED of Leucaena leaves was the lowest $(p<0.001)$ among the six samples. Rain tree leaves, Para, and Napier grasses had the greatest rapidly soluble fractions. The potentially degradable fractions of Leucaena and Gliricidia leaves were greater $(p<0.01)$ than those of Rain tree leaves and Para grass. Napier grass had greater $(p<0.001)$ ED than all the other samples except Gliricidia leaves.

For each nutrient, degradation rates (c) of the samples did not differ significantly from one another.

\section{In Vitro Gas Production}

The resulting cumulative gas production curves from the in vitro fermentation of the six samples are presented in Figure 2 and the estimated gas production parameters are given in Table 4. All six samples had negative values for the gas production from the immediately soluble fraction (a). Napier grass had a lower 
Table 3. Effective degradability and estimated degradation kinetics of the samples incubated in the rumen

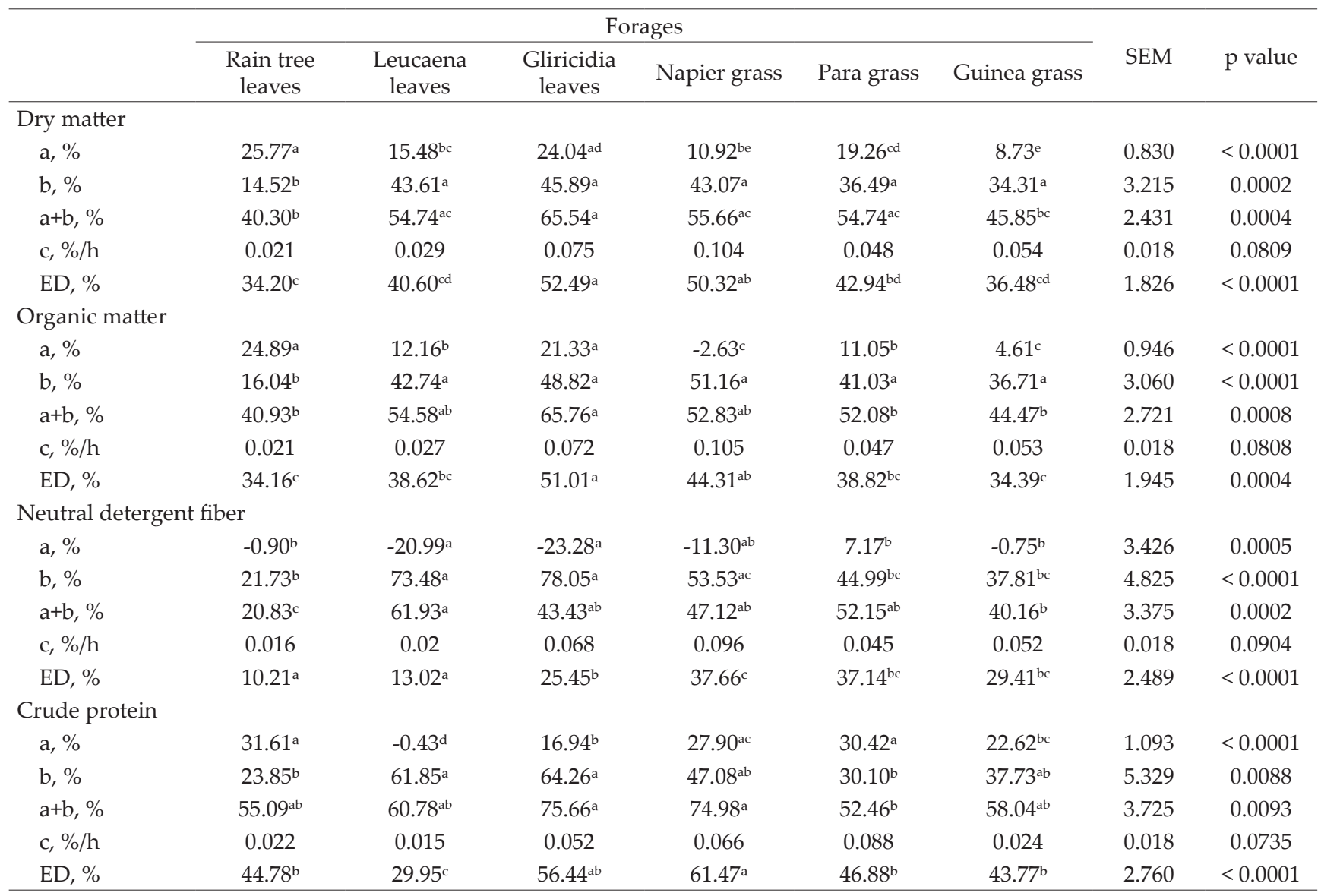

Note: Means in the same row with different superscripts differ significantly $(\mathrm{p}<0.05)$. a: the rapidly soluble fraction $(\%)$, b: the potentially degradable fraction (\%), c: degradation rates, ED: effective degradability.

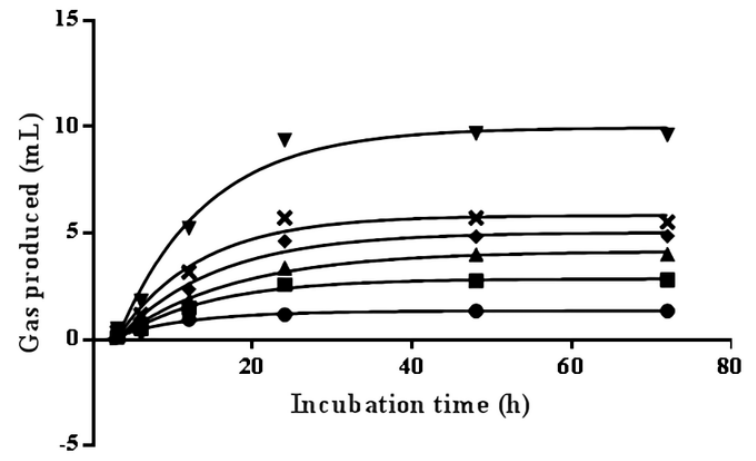

Figure 2. Cumulative gas production profiles of the samples that were subjected to the in vitro gas production experiment; - - rain tree leaves; - - - Leucaena leaves;

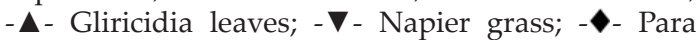
grass; -x- Guinea grass.

$(\mathrm{p}<0.01)$ gas production from the immediately soluble fraction than Rain tree and Leucaena leaves. Although the gas production from the immediately soluble fraction of Napier grass was lower, its gas production from the insoluble fraction (b) was the greatest $(p<0.001)$ among the six samples. As a result, its potential gas production $(a+b)$ was also the greatest $(p<0.001)$ out of all the samples.
Unlike the nutrient degradation rates analyzed in Experiment 1, there was a significant difference $(p<0.05)$ in the gas production rates (c) among the samples. Rain tree leaves, which had the lowest potential gas production, had a higher rate of gas production than Gliricidia leaves.

\section{Correlation between the Effective Degradability and the Gas Production Parameters}

The ED of each nutrient which was calculated in Experiment 1 was subjected to correlation analysis with the gas production at each incubation time (Table 5 ) as well as with the estimated gas production parameters (Table 6). Effective degradability of DM was only found to be moderately correlated with cumulative gas production at $48 \mathrm{~h}$ and $72 \mathrm{~h}(\mathrm{p}<0.05)$. Effective degradability of OM, on the other hand, did not have any correlation with any of the gas production incubation times. NDF effective degradability exhibited the most correlations with the gas production measurements. It is moderately correlated with cumulative gas production at $6 \mathrm{~h}(\mathrm{p}<0.05)$ and $12 \mathrm{~h}(\mathrm{p}<0.01)$ and strongly correlated with cumulative gas production at $24 \mathrm{~h}, 48 \mathrm{~h}$ and $72 \mathrm{~h}$ $(p<0.001)$. Effective degradability of CP also showed correlations with cumulative gas productions at certain 
Table 4. Estimated gas production variables of the samples that were subjected to the in vitro gas production experiment

\begin{tabular}{lcccccccc}
\hline & \multicolumn{9}{c}{ Forages } & & \\
\cline { 2 - 6 } & $\begin{array}{c}\text { Rain tree } \\
\text { leaves }\end{array}$ & $\begin{array}{c}\text { Leucaena } \\
\text { leaves }\end{array}$ & $\begin{array}{c}\text { Gliricidia } \\
\text { leaves }\end{array}$ & Napier grass & Para grass & Guinea grass & SEM & p value \\
\hline $\mathrm{a}, \mathrm{mL}$ & $-0.36^{\mathrm{a}}$ & $-0.85^{\mathrm{a}}$ & $-0.95^{\mathrm{a}}$ & $-3.14^{\mathrm{b}}$ & $-1.71^{\mathrm{ab}}$ & $-1.90^{\mathrm{ab}}$ & 0.375 & 0.0067 \\
$\mathrm{~b}, \mathrm{~mL}$ & $1.61^{\mathrm{a}}$ & $3.71^{\mathrm{ab}}$ & $5.12^{\mathrm{ab}}$ & 13.13 & $6.46^{\mathrm{ab}}$ & $7.74^{\mathrm{b}}$ & 1.052 & 0.0001 \\
$\mathrm{a}+\mathrm{b}, \mathrm{mL}$ & $1.35^{\mathrm{a}}$ & $2.86^{\mathrm{ab}}$ & $4.18^{\mathrm{ab}}$ & 9.99 & $5.05^{\mathrm{b}}$ & $5.84^{\mathrm{b}}$ & 0.748 & $<0.0001$ \\
$\mathrm{c}, \mathrm{mL} / \mathrm{h}$ & $0.105^{\mathrm{a}}$ & $0.082^{\mathrm{ab}}$ & $0.061^{\mathrm{b}}$ & $0.093^{\mathrm{ab}}$ & $0.084^{\mathrm{ab}}$ & $0.097^{\mathrm{ab}}$ & 0.007 & 0.0426 \\
\hline
\end{tabular}

Note: Means in the same row with different superscripts differ significantly $(\mathrm{p}<0.05)$. a: the rapidly soluble fraction $(\%)$, b: the potentially degradable fraction (\%), c: degradation rates.

Table 5. Correlation coefficients ( $r$ ) of the relationship between the effective degradability of each nutrient with the cumulative gas production at every time interval

\begin{tabular}{ccccccc}
\hline & \multicolumn{7}{c}{ Incubation times } \\
\cline { 2 - 7 } & $3 \mathrm{~h}_{\text {gas }}$ & $6 \mathrm{~h}_{\text {gas }}$ & $12 \mathrm{~h}_{\text {gas }}$ & $24 \mathrm{~h}_{\text {gas }}$ & $48 \mathrm{~h}_{\text {gas }}$ & $72 \mathrm{~h}_{\text {gas }}$ \\
\hline $\mathrm{DM}_{i s}$ & $0.0451^{\mathrm{NS}}$ & $0.201^{\mathrm{NS}}$ & $0.345^{\mathrm{NS}}$ & $0.449^{\mathrm{NS}}$ & $0.519^{*}$ & $0.535^{*}$ \\
$\mathrm{OM}_{i s}$ & $-0.0627^{\mathrm{NS}}$ & $0.0255^{\mathrm{NS}}$ & $0.149^{\mathrm{NS}}$ & $0.249^{\mathrm{NS}}$ & $0.330^{\mathrm{NS}}$ & $0.346^{\mathrm{NS}}$ \\
$\mathrm{NDF}_{i s}$ & $0.265^{\mathrm{NS}}$ & $0.482^{*}$ & $0.639^{* *}$ & $0.766^{* * *}$ & $0.783^{* * *}$ & $0.785^{* * *}$ \\
$\mathrm{CP}_{i s}$ & $0.300^{\mathrm{NS}}$ & $0.388^{\mathrm{NS}}$ & $0.494^{*}$ & $0.558^{*}$ & $0.608^{* *}$ & $0.616^{* *}$ \\
\hline
\end{tabular}

Note: ${ }^{* * *} \mathrm{p}<0.001 ;{ }^{* *} \mathrm{p}<0.01 ;{ }^{*} \mathrm{p}<0.05 ; \mathrm{NS}=$ not significant $(\mathrm{p}>0.05) ; \mathrm{DM}=$ dry matter; $\mathrm{OM}=$ organic matter; NDF= neutral detergent fiber; $\mathrm{CP}=$ crude protein; is = in situ; gas $=$ in vitro.

Table 6. Correlation coefficients ( $\mathrm{r}$ ) of the relationship between the effective degradability of each nutrient with the estimated gas production parameters

\begin{tabular}{ccccc}
\hline & \multicolumn{4}{c}{ Estimated variables } \\
\cline { 2 - 5 } & $\mathrm{a}_{\text {gas }}$ & $\mathrm{b}_{\text {gas }}$ & $\mathrm{a}+\mathrm{b}_{\text {gas }}$ & $\mathrm{c}_{\text {gas }}$ \\
\hline $\mathrm{DM}_{i s}$ & $-0.389^{\mathrm{NS}}$ & $0.501^{*}$ & $0.534^{*}$ & $-0.667^{* *}$ \\
$\mathrm{OM}_{i s}$ & $-0.202^{\mathrm{NS}}$ & $0.311^{\mathrm{NS}}$ & $0.346^{\mathrm{NS}}$ & $-0.724^{* * *}$ \\
$\mathrm{NDF}_{i s}$ & $-0.687^{* *}$ & $0.772^{* * *}$ & $0.790^{* * *}$ & $-0.380^{\mathrm{NS}}$ \\
$\mathrm{CP}_{i s}$ & $-0.454^{\mathrm{NS}}$ & $0.580^{*}$ & $0.616^{* *}$ & $-0.318^{\mathrm{NS}}$ \\
\hline
\end{tabular}

Note: ${ }^{* * *} \mathrm{p}<0.001 ;{ }^{* *} \mathrm{p}<0.01 ;{ }^{*} \mathrm{p}<0.05$; NS $=$ not significant $(\mathrm{p}>0.05)$; is $=$ in situ; gas = in vitro; a = gas production from the immediately soluble fraction; $b=$ gas production from the insoluble fraction; $a+b=$ potential gas production; $\mathrm{c}=$ gas production rate.

time intervals. It was moderately correlated with cumulative gas production at $12 \mathrm{~h}$ and $24 \mathrm{~h}(\mathrm{p}<0.05)$, and strongly correlated at $48 \mathrm{~h}$ and $72 \mathrm{~h}(\mathrm{p}<0.01)$.

Effective degradability values of each nutrient were also found to be correlated with some of the estimated gas parameters $(a, b, a+b$, and $c)$. DM effective degradability was moderately correlated with the gas production from the insoluble fraction and the potential gas production $(\mathrm{p}<0.05)$, and strongly but negatively correlated with the rate of gas production $(p<0.01)$. OM effective degradability was found to be only correlated with gas production rate $(\mathrm{p}<0.001)$. Effective degradability of NDF was strongly correlated $(p<0.01)$ with the gas production from the rapidly soluble fraction, and strongly correlated with the gas production from the insoluble fraction and potential gas production $(\mathrm{p}<0.001)$. Lastly, effective degradability of $\mathrm{CP}$ was moderately correlated with the gas production from the insoluble fraction $(\mathrm{p}<0.05)$, and strongly correlated with the potential gas production $(\mathrm{p}<0.01)$.

\section{DISCUSSION}

\section{In Situ Degradability of DM, OM, NDF, and CP}

Rain tree is a legume species with high tannin content (Anantasook et al., 2014). Tannin is an example of a plant secondary metabolite whose primary purpose is to protect the plant from foreign attacks such as from microbial pathogens (Kisworo et al., 2017). Tannin reduces DM degradability of forages by forming complexes with many compounds like polysaccharides, proteins, nucleic acids, steroids, and saponins (Ozkan \& Sahin, 2006). Lignin present in the Rain tree sample may have also contributed to its poor DM degradability. The measured lignin content of Rain tree foliage in a study by Delgado et al. (2014) was $14.8 \%$. This value is relatively greater than the lignin content of Gliricidia leaves (12.19\%) (Ahmed et al., 2018) and of Napier grass (13\%) (Liong et al., 2013), the two forages with the greatest DM effective degradability in the present study. Like tannin, lignin limits the DM degradability of feed materials because of the cross-linking of this compound with the other cell wall polysaccharides (Niwińska, 2012; Moreira et al., 2013). Gliricidia has a relatively low tannin content (Ahmed et al., 2018) which is why it has the greatest $(P<$ 0.001) calculated ED together with Napier grass.

Para grass is the only sample tested that does not have a negative rapidly soluble NDF fraction. This means that NDF degradation for the other samples actually begin after a certain initiation duration. However, the negative values for the rapidly soluble NDF fractions of Leucaena and Gliricidia leaves may be due to the negative NDF degradations measured at the early periods of their incubation. While very unlikely, one possible reason for this is that small fractions of NDF 
from the digesta in the rumen percolated into the bags and was included in the analysis of the samples. On the other hand, the longer lag phase for Napier and Para grasses may indicate that undegradable components in the plant cell wall prevents the microbes to colonize the samples immediately (Corrêa et al., 2014).

As with the other legumes in the study, Leucaena leaves also exhibited a reduction in CP degradability due to its tannin content (Paengkoum et al., 2013; Foroughbakhch et al., 2012). The tannins may have

Table 7. Correlation coefficients (r) of the relationship between the dry matter degradation and gas production per forage

\begin{tabular}{lcc}
\hline Forages & Correlation coefficients $(\mathrm{r})$ & $\mathrm{P}$ value \\
\hline Rain tree leaves & 0.934 & 0.0064 \\
Leucaena leaves & 0.922 & 0.0088 \\
Gliricidia leaves & 0.979 & 0.0006 \\
Napier grass & 0.981 & 0.0005 \\
Para grass & 0.960 & 0.0023 \\
Guinea grass & 0.950 & 0.0036 \\
\hline
\end{tabular}

formed complexes with proteins (Ozkan \& Sahin, 2006) leading to a low CP degradability in the bags. In addition, a portion of the protein that escaped the digestion bags may have been in the form of protein-tannin complexes which were undegraded by the microorganisms in the rumen (Nsahlai et al., 1999; McNabb et al., 1996; Perez-Maldonado \& Norton, 1996 as cited by Morais et al., 2018). This is one of the limitations of the nylon bag technique when applied to tanniferous samples. In any case, the low CP degradability of Leucaena leaves

Table 8. Effective degradability predictor models derived from the gas production and estimated parameters

\begin{tabular}{lcccc}
\hline & Equation & $\mathrm{R}^{2}$ & $\mathrm{p}$ value & Aic \\
\hline $\mathrm{DM}$ & $\mathrm{y}=65.88+0.99 \mathrm{gas}_{72 \mathrm{~h}}-310.01 \mathrm{c}_{\text {gas }}$ & 0.740 & 0.0002 & 47.47 \\
$\mathrm{OM}$ & $\mathrm{y}=65.77+0.46 \mathrm{gas}_{72 \mathrm{~h}}-309.29 \mathrm{c}_{\text {gas }}$ & 0.659 & 0.0009 & 48.94 \\
$\mathrm{NDF}$ & $\mathrm{y}=23.58+3.93 \mathrm{gas}_{72 \mathrm{~h}}-181.73 \mathrm{c}_{\text {gas }}$ & 0.813 & $<0.0001$ & 56.76 \\
$\mathrm{CP}$ & $\mathrm{y}=33.45+5.98$ gas $_{72 \mathrm{~h}}+10.13 \mathrm{a}_{\text {gas }}$ & 0.500 & 0.0055 & 79.08 \\
\hline
\end{tabular}

Note: $\mathrm{DM}=$ dry matter; $\mathrm{OM}=$ organic matter; $\mathrm{NDF}=$ neutral detergent fiber; $\mathrm{CP}=$ crude protein.

Table 9. Effective nutrient degradability values of some forages calculated using predictor models

\begin{tabular}{|c|c|c|c|c|c|c|}
\hline \multirow{2}{*}{ Forages } & \multirow{2}{*}{ Scientific name } & \multirow{2}{*}{$\mathrm{DM}(\%)$} & \multicolumn{4}{|c|}{ Calculated effective degradability values (\%) } \\
\hline & & & $\mathrm{DM}$ & $\mathrm{OM}$ & NDF & $\mathrm{CP}$ \\
\hline Guinea grass, $21 \mathrm{~d}$ & Panicum maximum & 29.41 & 49.90 & 47.75 & 27.39 & 45.75 \\
\hline Guinea grass, $42 \mathrm{~d}$ & Panicum maximum & 29.44 & 47.04 & 45.07 & 24.65 & 45.62 \\
\hline Guinea grass, $56 \mathrm{~d}$ & Panicum maximum & 37.12 & 46.49 & 44.70 & 23.16 & 44.70 \\
\hline Napier grass, $21 \mathrm{~d}$ & Pennisetum purpureum & 15.38 & 53.11 & 49.44 & 38.87 & 58.46 \\
\hline Napier grass, $42 \mathrm{~d}$ & Pennisetum purpureum & 15.52 & 50.31 & 46.80 & 36.22 & 55.14 \\
\hline Napier grass, $56 \mathrm{~d}$ & Pennisetum purpureum & 17.33 & 47.76 & 43.94 & 36.74 & 58.13 \\
\hline Napier grass (Florida), $45 \mathrm{~d}$ & Pennisetum purpureum & 17.74 & 34.83 & 31.02 & 29.33 & 47.40 \\
\hline Centrosema, $42 \mathrm{~d}$ & Centrosema pubescens & 28.57 & 40.99 & 38.38 & 25.23 & 43.58 \\
\hline Centrosema, $63 \mathrm{~d}$ & Centrosema pubescens & 31.25 & 50.48 & 47.89 & 30.46 & 51.65 \\
\hline Centrosema, $84 \mathrm{~d}$ & Centrosema pubescens & 29.03 & 55.09 & 52.33 & 34.28 & 56.39 \\
\hline Alabang grass, $28 \mathrm{~d}$ & Dicanthum annulatum & 20.93 & 49.16 & 46.46 & 30.47 & 48.21 \\
\hline Alabang grass, $56 \mathrm{~d}$ & Dicanthum annulatum & 30.07 & 44.80 & 42.29 & 26.74 & 45.96 \\
\hline Star grass, $56 \mathrm{~d}$ & Cynodon nlemfuensis & 24.53 & 47.81 & 45.29 & 28.56 & 47.93 \\
\hline Gamba grass, $45 \mathrm{~d}$ & Andropogon gayanus & 37.09 & 43.21 & 40.84 & 24.97 & 47.32 \\
\hline Cogon grass, $56 \mathrm{~d}$ & Imperata cylindrica & 40.00 & 26.56 & 24.70 & 12.26 & 39.49 \\
\hline Splendid grass, 45 d & Setaria splendida & 19.33 & 47.22 & 43.11 & 38.32 & 57.49 \\
\hline Golden Timothy, 56 d & Setaria sphacelata & 25.00 & 42.61 & 37.95 & 39.14 & 56.08 \\
\hline Leucaena tops & Leucaena leucocephala & 27.24 & 49.82 & 47.07 & 31.13 & 47.32 \\
\hline Corn silage & Zea mays & 31.71 & 41.80 & 40.01 & 20.46 & 44.82 \\
\hline Perennial Stylo & Stylosanthes guianensis & 20.44 & 53.71 & 49.13 & 44.97 & 65.49 \\
\hline Flemengia & Flemengia macrophylla & 27.34 & 39.77 & 38.67 & 14.92 & 38.59 \\
\hline Sesbania & Sesbania grandiflora & 23.28 & 53.91 & 49.40 & 44.64 & 61.66 \\
\hline Sugarcane tops & Saccharum officinarum & 26.15 & 47.79 & 46.12 & 23.14 & 44.37 \\
\hline Calopo & Calopogonium muconoides & 30.38 & 55.09 & 51.49 & 39.53 & 60.22 \\
\hline Kudzu & Pueraria phaseoloides & 21.80 & 53.26 & 49.99 & 36.39 & 57.19 \\
\hline Moringa & Moringa oleifera & 22.45 & 56.48 & 53.47 & 36.66 & 59.46 \\
\hline Rice straw & Oryza sativa & 89.39 & 58.18 & 55.58 & 34.97 & 54.01 \\
\hline Rensonii & Desmodium rensonii & 20.33 & 62.90 & 59.52 & 42.66 & 58.98 \\
\hline Peanut hay & Arachis hypogea & 93.66 & 47.58 & 44.47 & 32.17 & 54.72 \\
\hline Pigeon pea straw & Cajanus cajan & 95.17 & 46.87 & 44.05 & 29.97 & 49.19 \\
\hline
\end{tabular}

Note: $\mathrm{DM}=$ dry matter; $\mathrm{OM}=$ organic matter; $\mathrm{NDF}=$ neutral detergent fiber; $\mathrm{CP}=$ crude protein. 
implies that the initial $\mathrm{CP}$ does not necessarily equate to the extent of CP degradability of a sample.

\section{In Vitro Gas Production}

Compared to the findings of Sujani et al. (2016) and Zailan et al. (2016), the gas production of the samples in the current study is substantially low (Figure 2). This may be because the conditions in the rumen fluid-buffer mixture in the current in vitro experiment were more adverse than those used in the mentioned studies. Those authors used a digestion medium described by Menke \& Steingass (1988) which contains a more complete set of macro and micro minerals. Still, the gas production curve of a sample obtained in the current experiment has a very strong correlation with the corresponding DM degradability curve obtained from Experiment 1 (Table 7). This result signifies that within each sample, the in situ incubation method and the in vitro gas production method will produce non-linear curves which are roughly similar in terms of the rate and extent of gas production/nutrient degradation.

\section{Prediction of Effective Degradability Using Gas Production Parameters}

The resulting predictor models for the computations of the ED of each nutrient using the estimated gas parameters are shown in Table 8 and the calculated effective nutrient degradability values of some commonly used forages in the Philippines using the predictor models are presented in Table 9. The predictor model for the DM ED has a coefficient of determination of 0.740 which indicates that the gas parameters present in the equation explain $74 \%$ of the variability in the DM ED of the forages. The predictor model for OM ED had a lower coefficient of determination which was only 0.659 . The equation for NDF ED had the greatest coefficient of determination which was 0.813 . This is a justification that most of the gas produced during fermentation in the rumen comes from the degradation of plant cell wall components by the rumen microbes. On the other hand, CP ED predictor only had a coefficient of determination of 0.500 . Gas production from CP degradation mostly comes indirectly from the fermentation of the carbohydrates required to drive protein metabolism and synthesis (McDonald et al., 2010).

\section{CONCLUSION}

The gas production and the estimated gas parameters obtained using the modified in vitro technique used in the present study can be used to estimate the in situ ruminal degradability of forages. The resulting coefficient of determination $\left(\mathrm{R}^{2}\right)$ of the predictor models for the ED of DM, OM, and NDF were sufficiently strong while that of $\mathrm{CP}$ was only moderate.

\section{CONFLICT OF INTEREST}

The authors declare that there is no conflict of interest with any financial, personal, or other relationships with other people or organization related to the material discussed in the manuscript.

\section{ACKNOWLEDGEMENT}

This research would not have been possible without the financial support of the Philippine Department of Science and Technology - Science Education Institute and the Philippine Society of Animal Nutritionists; and the collaboration with the Philippine Carabao Center at University of the Philippines Los Baños.

\section{REFERENCES}

Ahmed, M. A., S. Jusoh, A. R. Alimon, M. Ebrahimi, \& A. A. Samsudin. 2018. Nutritive and anti-nutritive evaluation of Kleinhovia hospita, Leucaena leucocephala and Gliricidia sepium with respect to their effects on in vitro rumen fermentation and gas production. Trop. Anim. Sci. J. 41:128-136. https://doi.org/10.5398/tasj.2018.41.2.128

Anantasook, N., M. Wanapat, \& A. Cherdthong. 2014 Manipulation of ruminal fermentation and methane production by supplementation of rain tree pod meal containing tannins and saponins in growing dairy steers. J. Anim. Physiol. Anim. Nutr. 98:50-55. https://doi.org/10.1111/ jpn.12029

AOAC. 2016. Official Methods of Analysis of AOAC International. 22 ${ }^{\text {nd }}$ Edition. AOAC International.

Cone, J. W., M. A. M. Rodrigues, C. M. Guedes, \& M. C. Blok. 2009. Comparison of protein fermentation characteristics in rumen fluid determined with the gas production technique and the nylon bag technique. Anim. Feed Sci. Technol. 153:28-38. https://doi.org/10.1016/j.anifeedsci.2009.05.008

Corrêa, D. S., R. T. Magalhães, \& D. C. B. Siqueira. 2014 Ruminal dry matter and fiber fraction degradability from two stylos cultivars. Arq. Bras. Med. Vet. Zootec. 66:11551162. https://doi.org/10.1590/1678-6508

Delgado, D. C., R. Hera, J. Cairo, \& Y. Orta. 2014. Samanea saman, a multi-purpose tree with potentialities as alternative feed for animals of productive interest. Cuban J. of Agr. Sci. 48:205-212.

Edmunds, B., K. Südekum, H. Spiekers, \& F. Schwarz. 2012. Estimating ruminal crude protein degradation of forages using in situ and in vitro techniques. Animal Feed Science and Technology. 175:95-105. https://doi.org/10.1016/j. anifeedsci.2012.04.003

Foroughbakhch, P. R., A. C. Parra, A. R. Estrada, M. A. A. Vazquez, \& M. L. C. Avila. 2012. Nutrient content and in vitro dry matter digestibility of Gliricidia sepium (Jacq.) Walp. and Leucaena leucocephala (Lam. De Wit.). J. Anim. Vet. Adv. 11:1708-1712. https://doi.org/10.3923/ javaa.2012.1708.1712

Kamalak, A., O. Canbolat, Y. Gurbuz, \& O. Ozay. 2005. Comparison of in vitro gas production technique with in situ nylon bag technique to estimate dry matter degradation. Czech J. Anim. Sci. 50:60-67. https://doi. org/10.17221/3996-CJAS

Karlsson, L., M. Hetta, P. Udén, \& K. Martinsson. 2009. New methodology for estimating rumen protein degradation using the in vitro gas production technique. Anim. Feed Sci. Technol. 153:193-202. https://doi.org/10.1016/j. anifeedsci.2009.06.010

Kisworo, A. N., A. Agus, Kustantinah, \& B. Suwignyo. 2017. Physicochemical characteristics, in vitro fermentation indicators, gas production kinetics, and degradability of solid herbal waste as alternative feed source for ruminants. Med. Pet. 40:101-110. https://doi.org/10.5398/ 
medpet.2017.40.2.101

Liong, Y. Y., R. Halis, \& R. Mohamed. 2013. Chemical characterization of Imperata cylindrica ('Lalang') and Pennisetum purpureum (Napier grass) for bioethanol production in Malaysia. Pertanika J. Trop. Agric. Sci. 36:109-116.

McDonald, P., J. F. Greenhalgh, C. A. Morgan, R. Edwards, L. Sinclair, \& R. Wilkinson. 2010. Animal Nutrition. $7^{\text {th }}$ Edition. Pearson Canada.

McNabb, W. C., C. C. Waghorn, J. C. Peters, \& T. N. Barry. 1996. The effect of condensed tannins in Lotus pendunculatus on the solubilization and degradation of ribulose-1,5biphosphate carboxylase (EC 4.1.1.139; Rubisco) protein in the rumen and site of Rubisco digestion. Br. J. Nutr. 76:535549. https://doi.org/10.1079/BJN19960061

Mehrez, A. Z. \& E. R. Ørskov. 1977. A study of artificial fibre bag technique for determining the digestibility of feeds in the rumen. J. Agric. Sci. 88:645. (Abstr.)

Menke, K. H. \& H. Steingass. 1988. Estimation of the energetic feed value obtained from chemical analysis and in vitro gas production using rumen fluid. Animal Research and Development 28:7-55.

Mohamed, R. \& A. S. Chaudhry. 2008. Methods to study degradation of ruminant feeds. Nutr. Res. Rev. 21:68-81. https:// doi.org/10.1017/S0954422408960674

Morais, M. J., C. C. Sevilla, J. T. Dizon, G. L. Manulat, E. E. C. Abes, \& A. A. Angeles. 2018. Growth performance and ruminal metabolic variables of goats fed rain tree (Samanea saman) pods. Trop. Anim. Sci. J. 41:22-28. https://doi. org/10.5398/tasj.2018.41.1.22

Moreira, L. M., F. D. Leonel, R. A. Vieira, \& J. C. Pereira. 2013. A new approach about the digestion of fibers by ruminants. Revista Brasileira De Saúde E Produção Animal 14:382-395. https://doi.org/10.1590/ S1519-99402013000200008

Nsahlai, I. V., N. N. Umunna, \& P. O. Osuji. 1999. Influence of feeding sheep on oil seed cake following the consumption of tanniferous feeds. Livest. Prod. Sci. 60:59-59. https://doi. org/10.1016/S0301-6226(99)00036-6

Niwińska, B. 2012. Digestion in Ruminants. In: C. Chang, editor, Carbohydrates-Comprehensive Studies on Glycobiology and Glycotechnology. InTech. pp. 245-258. https://doi. org/10.5772/51574

NRC. 2001. Nutrient Requirements of Dairy Cattle. $7^{\text {th }}$ Edition. USDA, Washington, DC, USA.

Ørskov, E. R., F. D. Deb Hovell, \& F. Mould. 1980. The use of the nylon bag technique for the evaluation of feedstuffs. Trop. Anim. Prod. 5:195-213.

Ørskov, E. R. \& I. McDonald. 1979. The estimation of protein degradability in the rumen from incubation measurements weighted according to rate of passage. J. Agric. Sci. 92:499503. (Abstr.) https://doi.org/10.1017/S0021859600063048

Ozkan, C. O. \& M. Sahin. 2006. Comparison of in situ dry matter degradation with in vitro gas production of oak leaves supplemented with or without polyethylene glycol (PEG). Asian-Aust. J. Anim. Sci. 19:1120-1126. https://doi. org/10.5713/ajas.2006.1120

Paengkoun, P., S. Traiyakun, \& S. Paengkoun. 2013. Intestinal digestibility of enriched-protein fodders measured by mobile bag incubated with or without pepsin-HCL and threestep techniques. S. Afr. J. Anim. Sci. 43:511-518. https:/doi. org/10.4314/sajas.v43i4.8

Perez-Maldonado, R. A. \& B. W. Norton. 1996. Digestion of 14C-labelled condensed tannins from Desmodium intortum in sheep and goats. Br. J. Nutr. 76:501-513. https://doi. org/10.1079/BJN19960059

Sujani, S., I. N. Pathirana, R. T. Seresinhe, \& K. B. Dassanayaka. 2016. In vitro effects of exogenous fibrolytic enzymes on rumen fermentation of wild Guinea grass (Panicum maximum). Iran J. Appl. Anim. Sci. 6:303-308.

Zailan, M. Z., H. Yaakub, \& S. Jusoh. 2016. In vitro digestibility and gas production characteristics of four Napier (Pennisetum purpureum) cultivars as fresh fodder. Mal. J. Anim. Sci. 19:95-106. 